Ethiopian Journal of Environmental Studies \& Management 9(Suppl. 2): 1059 - 1070, 2016. ISSN:1998-0507 doi: http://dx.doi.org/10.4314/ejesm.v9i2.11S

Submitted: September 22, 2016

Accepted: December 17, 2016

\title{
EVALUATION OF GROUNDWATER RESOURCE POTENTIAL IN RURAL PART OF NORTHCENTRAL NIGERIA USING VERTICAL ELECTRICAL RESISTIVITY METHOD
}

\author{
*IBRAHIM, K.0.1, 2 AND GOMO, M. ${ }^{1}$ \\ ${ }^{1}$ Institute for Groundwater Studies, University of the Free State, Bloemfontein, South \\ Africa \\ ${ }^{2}$ Department of Geology and Mineral Sciences, Faculty of Physical Sciences, \\ University of Ilorin, P.M.B.1515, Ilorin, Kwara State, Nigeria
}

\begin{abstract}
This study was carried out to determine groundwater potential in the rural area of Northcentral Nigeria using Vertical Electrical Sounding (VES). The VES data was generated from twenty (20) locations in the study area and was later processed and analyzed using IPI2 WIN software. The underlying geo-electric sections comprises of top soil, laterites, weathered basement, fractured basement and fresh basement. The top soil have resistivity and thickness ranges between $44.1-862 \Omega m$ and $0.5-3.52 m$, second layer which is laterites possess resistivity and thickness between 16.3 - $2001 \Omega \mathrm{m}$ and $0.62-10.3 \mathrm{~m}$, third layer is weathered basement having resistivity and thickness ranges from 11.0 - $755 \Omega m$ and 3.1 - 52.0m while the fourth layer considered as fractured basement has resistivity and thickness between 93.1 - $3247 \Omega m$ and $14.8-71.1 \mathrm{~m}$ and final layer is fresh basement which possess resistivity ranges between $73.7-8444 \Omega \mathrm{m}$. The interpretation from the resistivity log of regolith rocks shows different curve types which include $\mathrm{HA}, \mathrm{HKH}, \mathrm{QH}, \mathrm{H}$ and $\mathrm{A}$ - type curves. About 55\% of the regolith in the area possesses aquifer potential value of 10.5 which shows optimum weathering and groundwater potential, therefore, any future borehole should be sited in these locations which are 3, 4, 8, 9, 10, 12, 13, 14, 16, 18 and 20. This study will provide a baseline hydrogeophysical data bank for prospective scientists, agriculturalists and relevant agencies that may be concerned with rural water supply and food security
\end{abstract}

Kew Words: Groundwater potential, Vertical Electrical Sounding, Schlumberger Array, IPI2 WIN Software, Geo-electric section and Regolith

\section{Introduction}

Groundwater is considered as the most reliable source of water supply, though in most cases, its availability and usage in an area depends on the hydrogeological factors which includes rainfall and run-off, geological factors such as textures and structures of the subsurface formations, the higher the permeability and porosity of the reservoir rock, the more will be groundwater accumulation and quantity yield (Shrestha, 1977). Those unconsolidated sediments like valley fills, rivers, alluvial gravel beds, coarse to medium grained sandstone and gravels are the best groundwater potential aquifers. Evidence shows that about $1000 \mathrm{~km}^{2}$ of the world's 
aggregated groundwater is abstracted annually while about $67 \%$ said to be used for irrigation, $22 \%$ is used for domestic and about $11 \%$ used for industrial purposes (Siebert et al., 2010).

In the most rural communities of developing world especially in Africa, groundwater serves as a reliable source of water supply mostly in the form of shallow hand dug wells because high cost in facilities of borehole well is out of reach for common man (Amadi et al., 2011). This research aim at determine the groundwater potential and delineate different lithologies to predict possible depth for any future proposed borehole site in the rural community of Northcentral Nigeria.

\section{Study Area}

This study was carried out in OkeOyi, a rural community situated in Ilorin East Area of Kwara State in the Northcentral part of Nigeria (Figure 1). It is bounded by latitude $8^{0} 32^{\prime}$ and $8^{0} 36^{\prime}$ and longitude $4^{0} 39^{\prime}$ and $4^{0} 43^{\prime}$ which falls within the basement complex of Nigeria. People in the area including the farmers rely on wide and shallow hand dug wells as their primary source of water for domestic and irrigations uses.

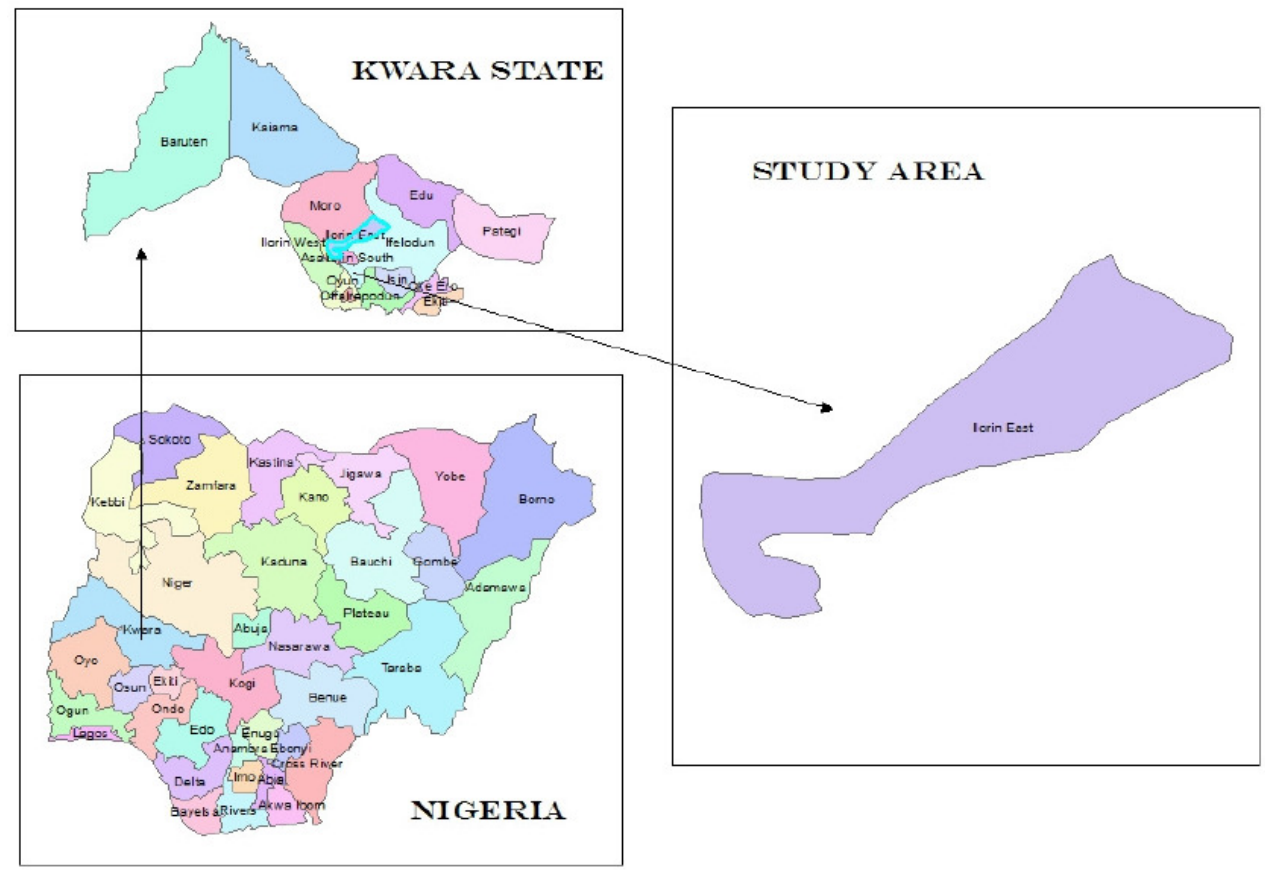

Figure 1: Map of Nigeria showing study location

The geology of the area is underlain by crystalline rocks of basement complex. Different types of crystalline rocks are found in various parts of the area, among which are migmatite - gneiss, banded gneiss, granite gneiss, augen gneiss, quatzites, older granites and also observed are the intrusions of pegmatitic rocks. The crystalline rocks possess porosities of less than 3\% (Bouwer,
1978). Rocks of basement complex, when not weathered are said not to be permeable and produce no storage capacity. Some appreciable amount of porosity and permeability might be developed in the rocks through fracturing and weathering processes (Davis and De Wiest, 1966), depending on the lithology and textural characteristics of the parent rock. According to Offordile (1983), 
Jones and Hockey (1985) and Egboka (1988), they described the units of basement rocks to very productive at the base of the weathered zone where the rocks might have been broken down to sand size and to larger fragments that are not subjected to extensive weathering process

\section{Materials and Methods}

The vertical electrical resistivity soundings (VES) using Schlumberger array was carried out in twenty (20) locations within the study area (Figure 2) following standard procedure to determine geoelectrical parameters and groundwater potential in the area.

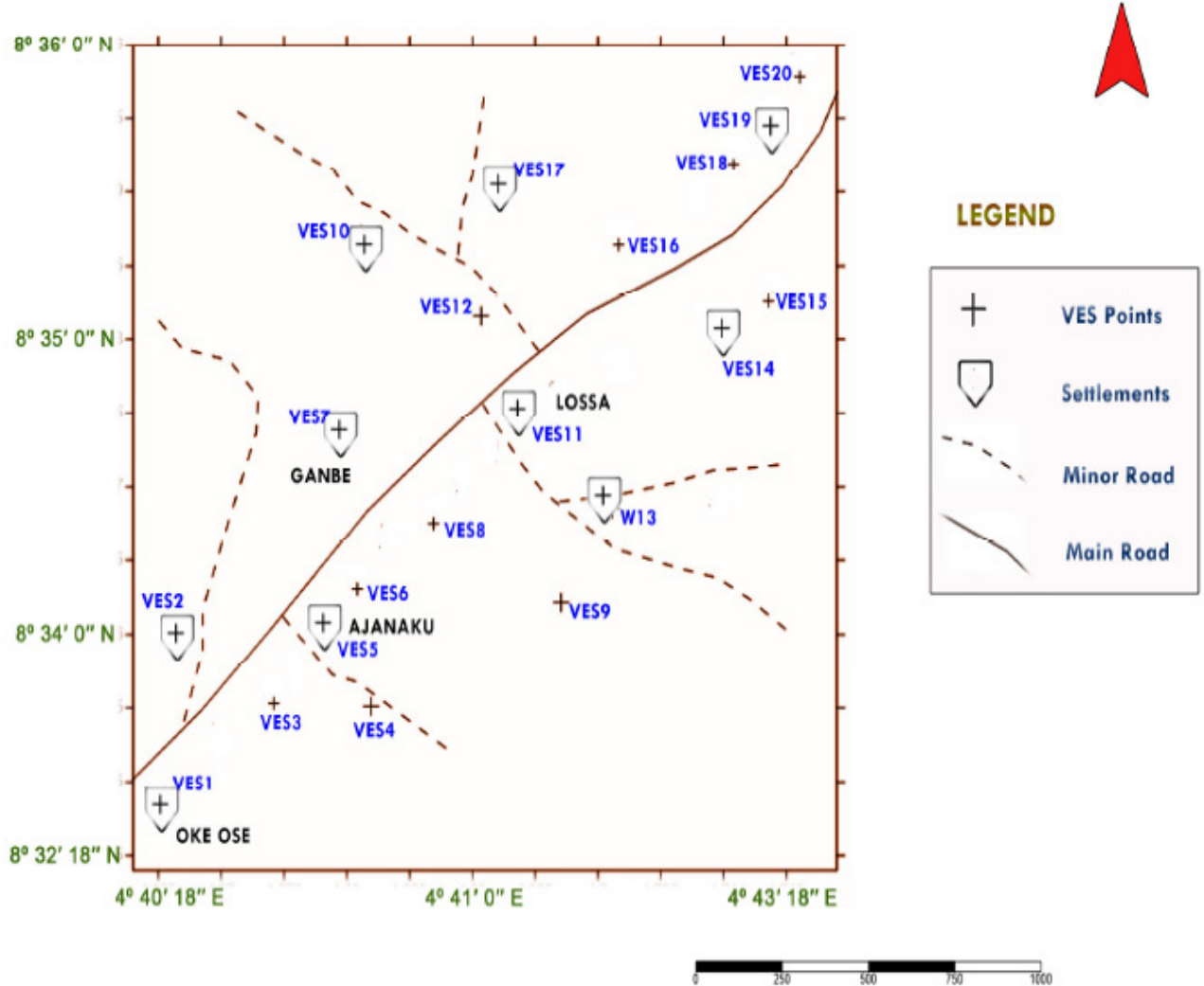

Figure 2: Layout map of study area showing VES Locations

During the field exercise, two current electrodes named $\mathrm{A}$ and $\mathrm{B}$ with two potential electrodes called $\mathrm{M}$ and $\mathrm{N}$ were placed in line with one another and centred on some locations but the potential and current electrodes were not placed equidistant from one another. Current was passed in to the ground through current electrodes while potential electrodes were then used quantitatively to measure the voltage system on the surface producing from the current flow patterns by the first set of electrodes.

The resistivity data was acquired through resistivity meter MODEL SSR $\mathrm{MP} 1 . \mathrm{AB} / 2$ was increased to a maximum spread of $100 \mathrm{~m}$ while $\mathrm{MN} / 2$ was increased to maximum of $15.0 \mathrm{~m}$. 


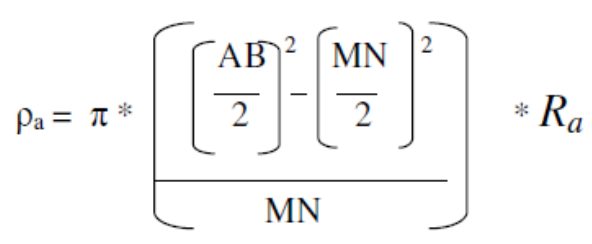

\section{Equation 1}

$\mathrm{AB}$ is distance between the two current electrodes while $\mathrm{MN}$ is distance between potential electrodes; $R_{\mathrm{a}}$ is called apparent electrical resistance given by the resistivity meter. However, the above equation can be rewrite as:

$$
\rho_{\mathrm{a}}=\mathrm{K} * R_{a}
$$

Equation 2

$\mathrm{K}$ is called geometrical factor:

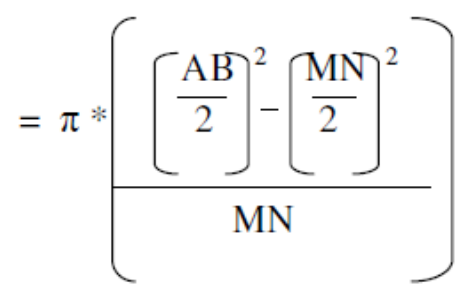

\section{Equation 3}

\section{Results and Data Interpretation}

The VES data obtained from the field are shown in (Table 1 and 2) which include current electrode spacing $(\mathrm{AB} / 2)$ in meters, potential electrode spacing (MN/2) in meters, geometrical factor (k) and the apparent resistivity value $\mathrm{R}(\Omega \mathrm{m})$ for each sounding point. The sounding curve that is given over a horizontal stratified medium depends basically on the factors which include layer thickness and electrode configuration (Zohdy, 1974). The VES data from the field were initially plotted on the bi-log graph through which the partial curve matching was obtained and layer resistivity values were used as initial background values which later inverted into $1 \mathrm{D}$ resistivity images using IPI2 WIN software.
However, IPI2 WIN software was based on the Newton algorithm (Bobachev, 2003) and usefulness of this software is that each of the considered layers is identified and converted appropriately along the sounding profiles.

The common curve types obtained from the processed data are $\mathrm{HA}, \mathrm{HKH}$, $\mathrm{QH}, \mathrm{H}$ and $\mathrm{A}$ as shown in (Figure 3) which also indicates different resistivity variations with their depth and lithology. It was observed that the curves are varies in the study area. The black lines in the curves shows the field curve, red and blue lines are indicating the inverted curves that gives information on the relationship that exists between the $\mathrm{AB} / 2$ and apparent resistivity value. 
Ethiopian Journal of Environmental Studies and Management Vol. 9 (Suppl. 2) 2016

Table 1: Apparent resistivity values obtained from the Field

\begin{tabular}{lllllllllllll}
\hline Current & $\begin{array}{l}\text { Potential } \\
\text { Factor }\end{array}$ & $\begin{array}{l}\text { Geometrical } \\
\text { Factor }\end{array}$ & $\begin{array}{l}\text { VES1 } \\
(\mathrm{R})\end{array}$ & $\begin{array}{l}\text { VES2 } \\
(\mathrm{R})\end{array}$ & $\begin{array}{l}\text { VES3 } \\
(\mathrm{R})\end{array}$ & $\begin{array}{l}\text { VES4 } \\
(\mathrm{R})\end{array}$ & $\begin{array}{l}\text { VES5 } \\
(\mathrm{R})\end{array}$ & $\begin{array}{l}\text { VES6 } \\
(\mathrm{R})\end{array}$ & $\begin{array}{l}\text { VES7 } \\
(\mathrm{R})\end{array}$ & $\begin{array}{l}\text { VES8 } \\
(\mathrm{R})\end{array}$ & $\begin{array}{l}\text { VES9 } \\
(\mathrm{R})\end{array}$ & $\begin{array}{l}\text { VES10 } \\
(\mathrm{R})\end{array}$ \\
\hline $\mathrm{AB} / 2(\mathrm{~m})$ & $\mathrm{MN} / 2(\mathrm{~m})$ & $\mathrm{K}$ & $(\Omega \mathrm{m})$ & $(\Omega \mathrm{m})$ & $(\Omega \mathrm{m})$ & $(\Omega \mathrm{m})$ & $(\Omega \mathrm{m})$ & $(\Omega \mathrm{m})$ & $(\Omega \mathrm{m})$ & $(\Omega \mathrm{m})$ & $(\Omega \mathrm{m})$ & $(\Omega \mathrm{m})$ \\
1.0 & 0.5 & 2.36 & 841.6 & 208.6 & 395 & 35.4 & 1227 & 109 & 95.3 & 1279 & 241 & 96.8 \\
2.0 & 0.5 & 11.78 & 943.8 & 150.7 & 320 & 42.6 & 729 & 111 & 14.5 & 1036 & 52.0 & 106 \\
3.0 & 0.5 & 13.75 & 787.2 & 76.6 & 302 & 22.0 & 254 & 40.2 & 108 & 994 & 27.0 & 110 \\
5.0 & 0.5 & 77.77 & 591.4 & 152.1 & 265 & 44.1 & 428 & 125 & 417 & 743 & 17.0 & 46.0 \\
6.0 & 0.5 & 112.3 & 677.3 & 126.3 & 216 & 38.7 & 434 & 141 & 211 & 512 & 18.0 & 87.0 \\
6.0 & 1.0 & 54.99 & 675.5 & 122.2 & 220 & 37.9 & 393 & 103 & 365 & 579 & 28.0 & 46.2 \\
8.0 & 1.0 & 98.97 & 775.7 & 100.4 & 185 & 27.9 & 342 & 128 & 64.0 & 371 & 19.0 & 73.1 \\
10.0 & 1.0 & 155.5 & 820.4 & 97.8 & 148 & 26.8 & 349 & 164 & 232 & 274 & 19.0 & 23.4 \\
10.0 & 2.5 & 58.91 & 822.4 & 90.9 & 154 & 21.9 & 356 & 147 & 265 & 279 & 12.0 & 20.4 \\
15.0 & 2.5 & 137.5 & 893.5 & 87.2 & 129 & 22.2 & 262 & 144 & 244 & 90.0 & 17.4 & 41.3 \\
20.0 & 2.5 & 247.4 & 1329 & 78.9 & 99.0 & 26.2 & 180 & 96.0 & 303 & 99.0 & 22.3 & 30.4 \\
25.0 & 2.5 & 388.8 & 2013 & 123.2 & 33.0 & 32.0 & 143 & 80.0 & 141 & 62.0 & 26.4 & 34.2 \\
30.0 & 2.5 & 561.6 & 1610 & 134.3 & 41.1 & 22.7 & 371 & 58.0 & 333 & 99.1 & 32.7 & 165 \\
35.0 & 2.5 & 765.9 & 993.4 & 140.3 & 54.0 & 34.5 & 109 & 102 & 424 & 147 & 34.2 & 273 \\
40.0 & 2.5 & 1001.5 & 1356 & 197.9 & 63.8 & 31.8 & 142 & 96.8 & 544 & 196 & 40.7 & 146 \\
40.0 & 7.5 & 323.4 & 1045 & 192.5 & 51.3 & 30.9 & 112 & - & 531 & 127 & 33.4 & 92.1 \\
50.0 & 7.5 & 511.9 & 1016 & 79.0 & 80.7 & 24.9 & 189 & 45.4 & 641 & 159 & 45.0 & 127 \\
60.0 & 7.5 & 742.3 & 2503 & 132.1 & 96.4 & 28.6 & 102 & 80.0 & 693 & 155 & 52.3 & 177 \\
70.0 & 7.5 & 1014.6 & 2112 & 142.9 & 217 & 27.2 & 82.0 & 107 & 456 & 172 & 48.1 & 138 \\
80.0 & 7.5 & 1328.8 & 1843 & 138.4 & 191 & 28.2 & 94.0 & 332 & 487 & 148 & 54.2 & 238 \\
90.0 & 7.5 & 1684.9 & 3360 & 102.5 & 258 & 51.1 & 51.0 & 220 & 531 & 153 & 53.6 & 279 \\
100.0 & 7.5 & 2082.9 & 3730 & 149.1 & 273 & 97.8 & 98.0 & 228 & 609 & 163 & 54.2 & 316 \\
\hline
\end{tabular}

Table 2: Apparent resistivity values obtained from the Field

\begin{tabular}{lllllllllllll}
\hline Current & $\begin{array}{l}\text { Potential } \\
\text { Factor }\end{array}$ & $\begin{array}{l}\text { Geometrical } \\
\text { Factor }\end{array}$ & $\begin{array}{l}\text { VES } \\
11 \\
(\mathrm{R})\end{array}$ & $\begin{array}{l}\text { VES } \\
12(\mathrm{R})\end{array}$ & $\begin{array}{l}\text { VES } \\
13\end{array}$ & $\begin{array}{l}\text { VES } \\
14\end{array}$ & $\begin{array}{l}\text { VES } \\
15\end{array}$ & $\begin{array}{l}\text { VES 16 VES } \\
(\mathrm{R})\end{array}$ & $\begin{array}{l}\text { VES } \\
(\mathrm{R})\end{array}$ & $\begin{array}{l}\text { VES } \\
18(\mathrm{R})\end{array}$ & $\begin{array}{l}\text { VES } \\
19(\mathrm{R})\end{array}$ & $\begin{array}{l}20 \\
(\mathrm{R})\end{array}$ \\
\hline $\mathrm{AB} / 2(\mathrm{~m})$ & $\mathrm{MN} / 2(\mathrm{~m})$ & $\mathrm{K}$ & $(\Omega \mathrm{m})$ & $(\Omega \mathrm{m})$ & $(\Omega \mathrm{m})$ & $(\Omega \mathrm{m})$ & $(\Omega \mathrm{m})$ & $(\Omega \mathrm{m})$ & $(\Omega \mathrm{m})$ & $(\Omega \mathrm{m})$ & $(\Omega \mathrm{m})$ & $(\Omega \mathrm{m})$ \\
1.0 & 0.5 & 2.36 & 427 & 682 & 657 & 491 & 470 & 211 & 161 & 116 & 131 & 409 \\
2.0 & 0.5 & 11.78 & 247 & 467 & 462 & 645 & 170 & 140 & 79.1 & 53.0 & 174 & 369 \\
3.0 & 0.5 & 13.75 & 273 & 394 & 101 & 382 & 79.7 & 35.3 & 28.1 & 35.0 & 248 & 301 \\
5.0 & 0.5 & 77.77 & 248 & 116 & 51.8 & 1038 & 134 & 33.5 & 33.8 & 43.0 & 172 & 224 \\
6.0 & 0.5 & 112.3 & 243 & 86.1 & 71.1 & 394 & 88.7 & 34.2 & 29.9 & 36.0 & 46.8 & 164 \\
6.0 & 1.0 & 54.99 & 233 & 88.4 & 73.7 & 292 & 119 & 28.3 & 29.7 & 41.2 & 37.2 & 144 \\
8.0 & 1.0 & 98.97 & 209 & 75.6 & 51.7 & 231 & 108 & 27.4 & 20.3 & 51.4 & 35.4 & 130 \\
10.0 & 1.0 & 155.5 & 183 & 84.4 & 32.5 & 183 & 63.9 & 29.2 & 18.5 & 60.0 & 26.6 & 125 \\
10.0 & 2.5 & 58.91 & 185 & 76.8 & 31.5 & 181 & 86.4 & 28.6 & 21.1 & 64.2 & 25.8 & 76.4 \\
15.0 & 2.5 & 137.5 & 185 & 25.6 & 40.7 & 114 & 45.8 & 51.9 & 20.5 & 93.1 & 24.2 & 39.8 \\
20.0 & 2.5 & 247.4 & 217 & 22.5 & 49.6 & 136 & 39.3 & 54.0 & 28.2 & 93.6 & 34.0 & 68.1 \\
25.0 & 2.5 & 388.8 & 363 & 34.0 & 54.6 & 159 & 64.8 & 82.6 & 14.3 & 104 & 31.4 & 80.6 \\
30.0 & 2.5 & 561.6 & 297 & 44.8 & 89.4 & 177 & 181 & 71.8 & 48.0 & 125 & 56.6 & 80.7 \\
35.0 & 2.5 & 765.9 & 275 & 73.3 & 100 & 198 & 134 & 89.4 & 24.6 & 143 & 84.6 & 101 \\
40.0 & 2.5 & 1001.5 & 292 & 69.1 & 71.8 & 230 & 134 & 68.0 & 45.5 & 166 & 86.3 & 110 \\
40.0 & 7.5 & 323.4 & 187 & 37.4 & 55.2 & 220 & 132 & 96.9 & 44.7 & 173 & 75.3 & 106 \\
50.0 & 7.5 & 511.9 & 174 & 101 & 79.8 & 303 & 40.0 & 140 & 52.5 & 196 & 108 & 124 \\
60.0 & 7.5 & 742.3 & 202 & 75.0 & 65.9 & 425 & 118 & 111 & 73.0 & 207 & 106 & 177 \\
70.0 & 7.5 & 1014.6 & 271 & 122 & 94.5 & 599 & 150 & 141 & 137 & 221 & 120 & 208 \\
80.0 & 7.5 & 1328.8 & 259 & 101 & 109 & 576 & 283 & 118 & 110 & 229 & 108 & 235 \\
90.0 & 7.5 & 1684.9 & 265 & 176 & 135 & 850 & 174 & 136 & 132 & 303 & 104 & 279 \\
100.0 & 7.5 & 2082.9 & 275 & 244 & 172 & 1214 & 348 & 183 & 117 & 318 & 111 & 342 \\
\hline
\end{tabular}




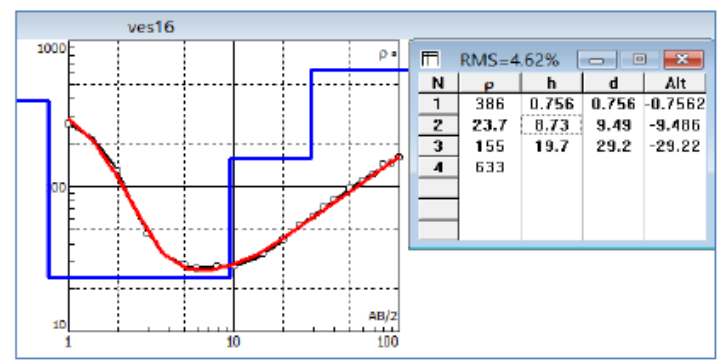

Figure 3a: Curve type $\mathrm{H}$

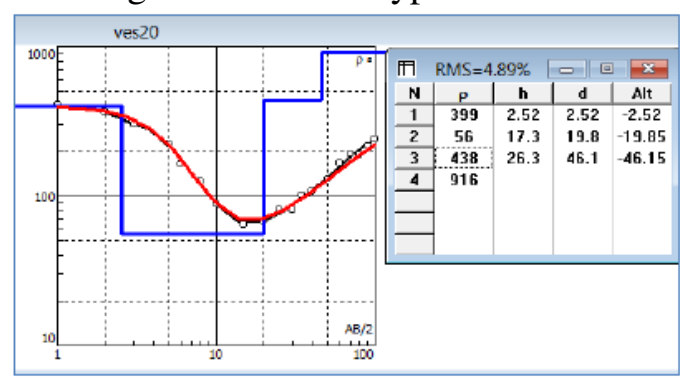

Figure 3c: Curve type QH

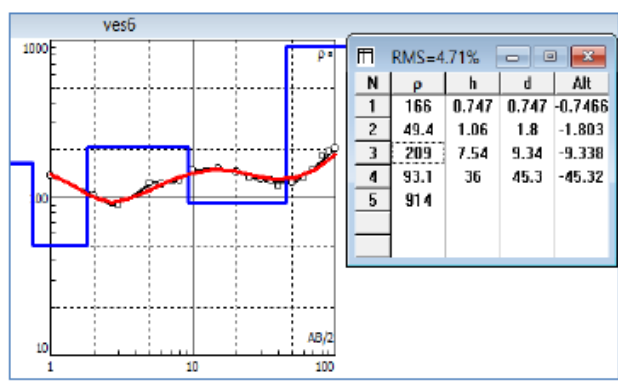

Figure 3b: Curve type HKH

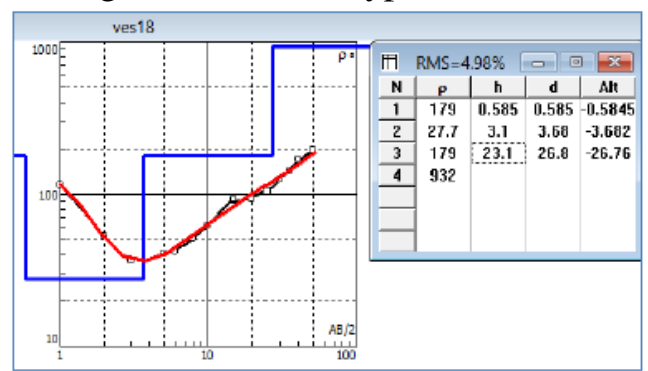

Figure 3d: Curve type HA

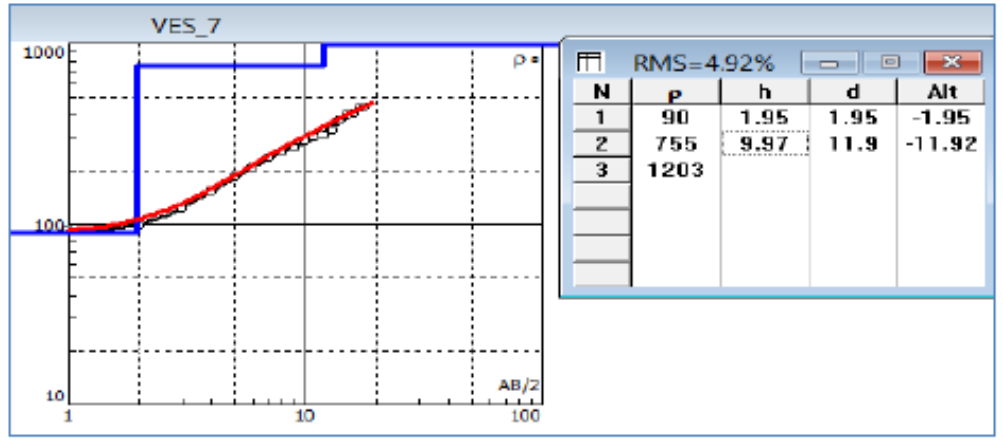

Figure 3e: Curve type A

\section{Geoelectrical Sections}

The interpretation of geophysical data could also be compared with hydrogeological and geological information (Lashkaripour and Nakhaei, 2005). In some cases, geo-electric sections that derived from the VES data interpretation do not always coincide with their corresponding real geological sections. Various lithological layers may display similar resistivity data and produce a single geo-electric layer. It is therefore necessary to have a good understanding of the underlying geology.

The characteristics nature of the curves obtained from the various VES data shows that the study area consist of three to five geoelectric layers which include top soil, lateritic layer, weathered basement, fractured basement and fresh basement. The results of this interpretation (Table 3 and 4 ) gives the characteristic of the top soil to have resistivity and thickness ranges between

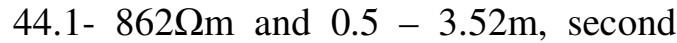
layer which is laterites possess resistivity and thickness between 16.3 - $2001 \Omega \mathrm{m}$ and $0.62-10.3 \mathrm{~m}$, third layer is weathered basement having resistivity and thickness ranges from $11.0-755 \Omega \mathrm{m}$ and $3.1-$ $52.0 \mathrm{~m}$ while the fourth layer considered as fractured basement has resistivity and thickness between $93.1-3247 \Omega m$ and $14.8-71.1 \mathrm{~m}$ and final layer is fresh 
basement which possess resistivity ranges between $73.7-8444 \Omega \mathrm{m}$. The resistivity contour map (Figure 4) indicate that the resistivity in first layer is very low especially in the central parts while extreme parts of the Northeast and Southwestern of the area possess relatively high resistivities. Lateritic second layer has high resistivities and these are obvious in most of the area except in Southwestern and localized parts of the central and Northeastern parts of the study area. Though, discrepancy (variation) in the resistivities of laterites is a common phenomenon especially in the basement terrain because when the laterites wet, they behaves like that as the ions in them are mobile and quickly acts in conduction. Third weathered basement layer is fairly high in resistivity in the North and Southwestern parts of the area while Southeast and Northeastern parts of the area are relatively low in resistivities which may be due to the percolation of clay into the layer which reduces its resistivities. The fourth layer consist of fractured basement and resistivity is generally high, though some resistivity values of less than two hundred also observed in some isolated places. Fifth layer comprises of very high resistivity in the main central and Southeastern parts which above one thousand-five hundred while in the localized North and Southwestern parts have resistivities around five hundred.

Table 3: Results of Computer Iteration of Resistivity Data

\begin{tabular}{lllllll}
\hline & \multirow{2}{*}{ VES } & \multirow{2}{*}{$\begin{array}{l}\text { No. of } \\
\text { STATION }\end{array}$} & Layers & Top & \multicolumn{3}{l}{ Weathered } & Fractured & Fresh \\
& & Soil & Laterite & Basement & Basement & Basement \\
\hline VES1 & 4 & - & 957 & 522 & 3247 & 5219 \\
VES2 & 5 & 248 & 90.9 & 223 & 93.1 & 496 \\
VES3 & 5 & 362 & 141 & 40.5 & 414 & 806 \\
VES4 & 4 & 44.1 & 16.3 & 50.0 & - & 73.7 \\
VES5 & 4 & - & 2001 & 335 & 78.4 & 292 \\
VES6 & 5 & 166 & 49.4 & 209 & 93.1 & 914 \\
VES7 & 3 & 90 & - & 755 & - & 1203 \\
VES8 & 4 & - & 1112 & 68.2 & 690 & 1698 \\
VES9 & 4 & - & 408 & 16.6 & 104 & 531 \\
VES10 & 5 & 98.3 & 117 & 23.9 & 408 & 8444 \\
VES11 & 4 & - & 426 & 174 & 277 & 401 \\
VES12 & 4 & - & 636 & 37.4 & 438 & 3126 \\
VES13 & 4 & - & 1009 & 38.0 & 371 & 549 \\
VES14 & 4 & - & 569 & 77.5 & 748 & 991 \\
VES15 & 4 & 862 & 106 & 11.0 & 531 & 1153 \\
VES16 & 4 & - & 386 & 23.7 & 155 & 633 \\
VES17 & 4 & 228 & - & 19.8 & 470 & 3224 \\
VES18 & 4 & 179 & - & 27.7 & 179 & 932 \\
VES19 & 4 & 176 & - & 14.3 & 297 & 716 \\
VES20 & 4 & 399 & - & 56.0 & 438 & 916 \\
\hline
\end{tabular}


Table 4: Thickness of Layer obtained from Resistivity Data

\begin{tabular}{lllllll}
\hline & \multirow{2}{*}{$\begin{array}{l}\text { VES } \\
\text { STATION }\end{array}$} & Layers & \multicolumn{2}{l}{ Thickness $(\mathrm{m})$} & & \\
\cline { 5 - 7 } Top Soi Laterite & $\begin{array}{l}\text { Weathered } \\
\text { Basement }\end{array}$ & $\begin{array}{l}\text { Fractured } \\
\text { Basement }\end{array}$ & $\begin{array}{l}\text { Fresh } \\
\text { Basement }\end{array}$ \\
\hline VES1 & 4 & 0 & 1.51 & 4.93 & 23.8 & - \\
VES2 & 5 & 0.78 & 10.3 & 20.6 & 62.3 & - \\
VES3 & 5 & 2.29 & 7.83 & 18.7 & 18.9 & - \\
VES4 & 4 & 3.52 & 7.72 & 52.0 & - & - \\
VES5 & 4 & - & 0.62 & 9.11 & 62.5 & - \\
VES6 & 5 & 0.75 & 1.06 & 7.54 & 36.0 & - \\
VES7 & 3 & 1.95 & - & 11.9 & & - \\
VES8 & 4 & - & 3.2 & 16.7 & 21.9 & - \\
VES9 & 4 & - & 0.55 & 15.0 & 22.5 & - \\
VES10 & 5 & 0.88 & 1.8 & 5.12 & 54.3 & - \\
VES11 & 4 & - & 1.33 & 8.58 & 71.1 & - \\
VES12 & 4 & - & 1.64 & 23.7 & 43.8 & - \\
VES13 & 4 & - & 0.93 & 15.7 & 42.4 & - \\
VES14 & 4 & - & 3.11 & 6.13 & 69.6 & - \\
VES15 & 5 & 0.5 & 5.03 & 3.37 & 29.1 & - \\
VES16 & 4 & - & 0.76 & 8.73 & 19.7 & - \\
VES17 & 4 & 0.72 & - & 16.5 & 14.8 & - \\
VES18 & 4 & 0.59 & - & 3.1 & 23.1 & - \\
VES19 & 4 & 2.24 & - & 7.4 & 29.1 & - \\
VES20 & 4 & 2.52 & - & 17.3 & 26.3 & - \\
\hline
\end{tabular}

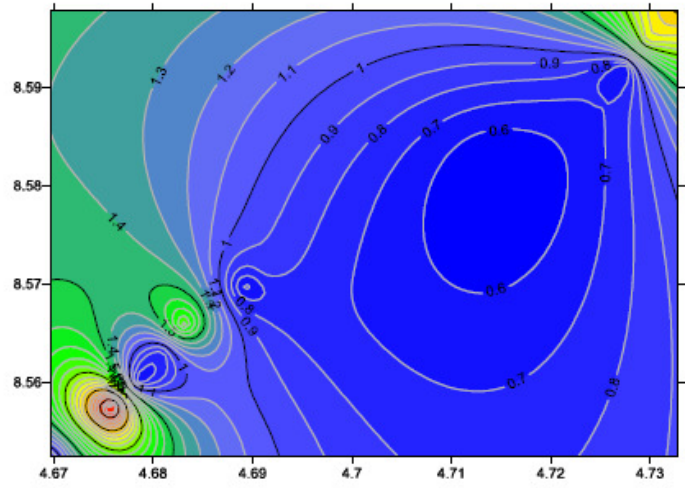

Fig.4a. Contour Resistivity Layer 1

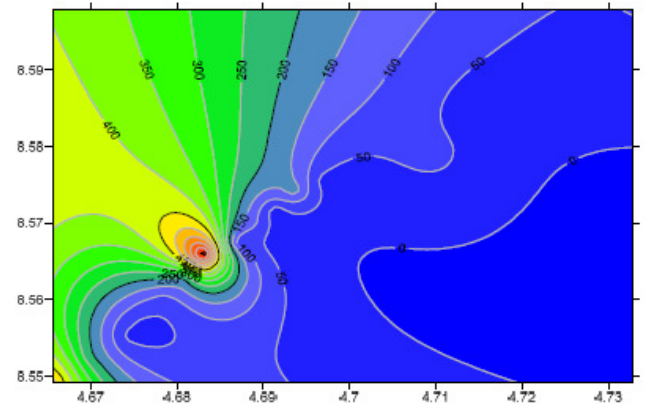

Fig.4c. Contour Resistivity Layer 3.

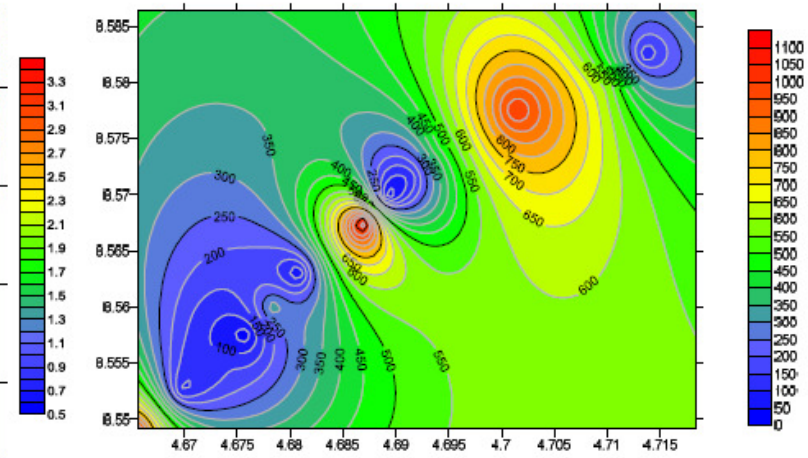

Fig.4b. Contour Resistivity Layer 2

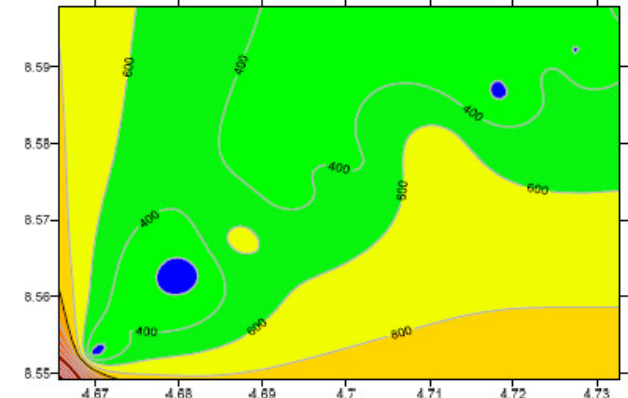

Fig.4d. Contour Resistivity Layer 4 


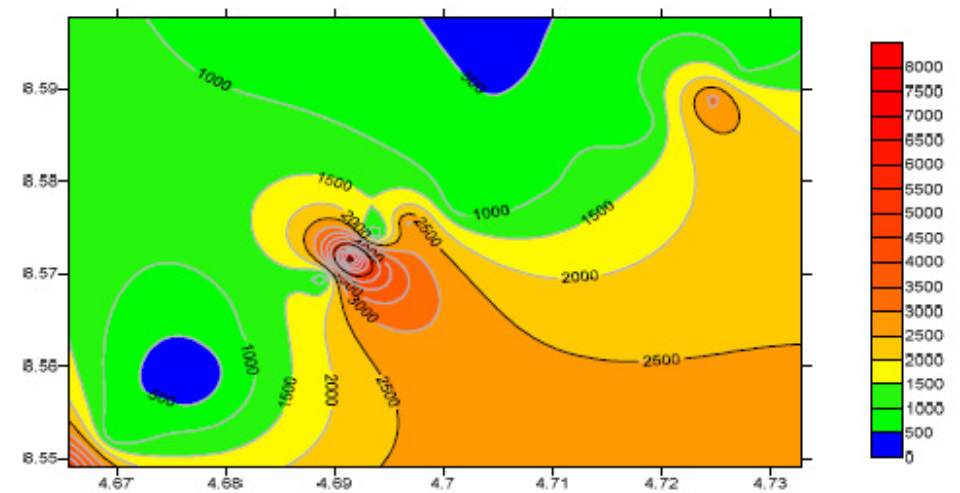

Fig. 4e. Contour Resistivity Layer 5

\section{Groundwater Potential}

In a hard rock terrain, the composite aquifers of the weathered basement and fractured basement are known to produce the highest groundwater yield (Oyedele and Olayinka, 2012). However, aquifer potential as a function of regolith resistitvity modified after (Oyedele and Olayinka, 2012) is presented in Table 5 below. Table 6 shows aquifer potential and characteristics in the study area. Hence, aquifer potential in the study area ranges from 2.5-10.5 and could be described as Optimum weathering and groundwater potential to Negligible. The analysis of resistivity data from the study area shows that $15 \%$ of the regolith in the study area has aquifer potential value of 5.0 which correspond to limited weathering and poor potential (VES 2, VES 6 and VES 11). Also, 15\% of the regolith in the study area has aquifer potential value of 7.0 and this gives clayey which possess limited aquifer potential (VES 15, VES 17 and VES 19). Furthermore, $15 \%$ of the regolith aquifer in the study area has aquifer potential value of 2.5 which is negligible (VES 1, VES 5 and VES 7). Finally, 55\% of the regolith in the study area have potential value of 10.5 and are characterized by optimum weathering and groundwater potential and these observed in VES 3, VES 4, VES 8, VES 9, VES 10, VES 12, VES 13, VES 14, VES 16, VES 18 and VES 20.

\section{Criteria for Selecting Good Borehole} Sites within Study Area

A common exploration strategy for groundwater in a crystalline basement terrains like this study area is to site water supply borehole where the regolith is thickest, the expectation being that it is under such circumstances that the saturated thickness is greater and the frequency of bedrock fissures also greater (Beeson and Jones, 1988; Carruthers and Smith, 1992; Chilton and Foster, 1995). However, in this aspect of research, there was a consideration on other parameters for deciding on the optimal and reliable borehole site.

A minimum thickness of $10 \mathrm{~m}$ for the overburden is often required in order to allow for the poor transmissivity of regolith aquifers. Since the yield of a well in this area is expected to be positively correlated with the depth to bedrock, there is assigned weights that are directly proportional to the overburden thickness, ranging from a minimum of 2.5 to a maximum of 10.5 as shown in Table 5 and Table 6 below. 
Table 5: Aquifer Potential as a Function of Regolith Resistivity

\begin{tabular}{lll}
\hline Regolith Resistivity $(\Omega-\mathrm{m})$ & Aquifer characteristics & Aquifer Potential \\
\hline$<20$ & $\begin{array}{l}\text { Clayey; limited aquifer potential } \\
\text { Optimum weathering and }\end{array}$ & 7.0 \\
groundwater potential & 10.5 \\
$20-100$ & $\begin{array}{l}\text { Medium aquifer conditions and } \\
\text { potential }\end{array}$ & 7.5 \\
$100-150$ & $\begin{array}{l}\text { Limited weathering and poor } \\
\text { potential }\end{array}$ & 5.0 \\
$150-300$ & Negligible & 2.5 \\
\hline 300 &
\end{tabular}

(Modified after Wright, 1992)

Table 6: Aquifer Potential and Characteristics in the study Area

\begin{tabular}{|c|c|c|c|c|}
\hline $\mathrm{S} / \mathrm{N}$ & VES & $\begin{array}{l}\text { Aquifer } \\
\text { Resistivity }\end{array}$ & $\begin{array}{l}\text { Aquifer } \\
\text { Potential }\end{array}$ & Aquifer characteristics \\
\hline 1 & VES1 & 522 & 2.5 & Negligible \\
\hline 2 & VES2 & 223 & 5.0 & Limited weathering and poor potential \\
\hline 3 & VES3 & 40.5 & 10.5 & Optimum weathering and groundwater potentia \\
\hline 4 & VES4 & 50.0 & 10.5 & Optimum weathering and groundwater potentia \\
\hline 5 & VES5 & 335 & 2.5 & Negligible \\
\hline 6 & VES6 & 209 & 5.0 & Limited weathering and poor potential \\
\hline 7 & VES7 & 755 & 2.5 & Negligible \\
\hline 8 & VES8 & 68.2 & 10.5 & Optimum weathering and groundwater potentia \\
\hline 9 & VES9 & 16.6 & 10.5 & Optimum weathering and groundwater potentia \\
\hline 10 & VES10 & 23.9 & 10.5 & Optimum weathering and groundwater potentia \\
\hline 11 & VES11 & 174 & 5.0 & Limited weathering and poor potential \\
\hline 12 & VES12 & 37.4 & 10.5 & Optimum weathering and groundwater potentia \\
\hline 13 & VES13 & 38.0 & 10.5 & Optimum weathering and groundwater potentia \\
\hline 14 & VES14 & 77.5 & 10.5 & Optimum weathering and groundwater potentia \\
\hline 15 & VES15 & 11.0 & 7.0 & Clayey; limited aquifer potential \\
\hline 16 & VES16 & 23.7 & 10.5 & Optimum weathering and groundwater potentia \\
\hline 17 & VES17 & 19.8 & 7.0 & Clayey; limited aquifer potential \\
\hline 18 & VES18 & 27.7 & 10.5 & Optimum weathering and groundwater potentia \\
\hline 19 & VES19 & 14.3 & 7.0 & Clayey; limited aquifer potential \\
\hline 20 & VES20 & 56.0 & 10.5 & Optimum weathering and groundwater potentia \\
\hline
\end{tabular}




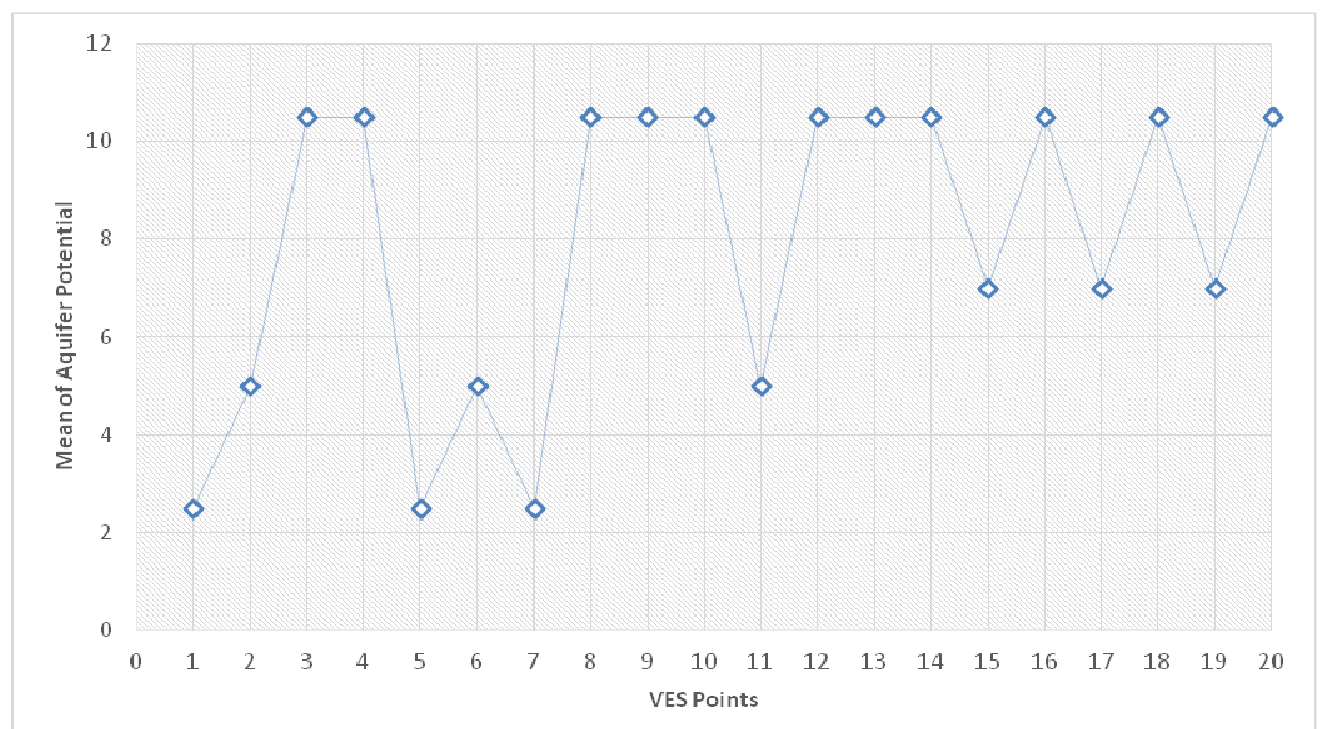

Figure 5: Aquifer Potential Pattern in the study Area

\section{Conclusion and Recommendation}

It can be concluded from the interpretation of the analyzed field data in the study area as follows; the study area is basically characterized with 3-5 lithological layers and the lithological layers correspond to top soil, laterites, weathered basement, fractured basement and fresh basement. However, the layer forming probable aquifer in the study area is weathered basement otherwise called saprolite or simply regolith. Hence, the regolith represents the deep seated aquiferous layer in the study area. The resistivity $\log$ of the regolith rocks in the study area are characterized by HA, $\mathrm{HKH}, \mathrm{QH}, \mathrm{H}$ and A- type curves. HAtype curves were obtained at VES1, VES 10, and VES 18. HKH - type curves obtained at VES 2 and VES 6. QH - type curves were obtained at VES 3 , VES 8, VES 11, VES 12, VES 13 and VES 20. H - Type curves were obtained at VES 4, VES 9, VES 14, VES 15, VES 16, VES 17 and VES 19 while the A - type curves obtained at VES 5and VES 7.

Finally, electrical resistivity technique has proved to be effective especially in identifying locations with high groundwater potential in the study area. It is therefore recommended that for any future borehole drilling in the study area, pre-drilling geophysical survey should be carried out and the borehole is recommended to be drilled where groundwater potential is 10.5 and thus have optimum weathering and groundwater potential which include locations $3,4,8,9,10,12,13,14,16,18$ and 20.

\section{References}

Amadi, A.N. (2010). Hydrogeological and geophysical study of Bosso Area of Minna, Northcentral Nigeria. Bayero Journal of Physics and Mathematical Sciences, 3(1): $66-73$.

Amadi, A.N., Nwawulu, C.D., Unuevho, C.I. and Olasehinde, P.I. (2011). Evaluation of Groundwater Potential in Pompo Village, Gidan Kwano, Minna Using Vertical Electrical Resistivity Soundings. British Journal of Applied Science and Technology, 1(3): $53-65$. 
Beeson, S. and Jones, C.R.C. (1998). The combined EMT/VES geophysical method for siting boreholes. Groundwater, 26: $54-63$.

Bobachev, C. (2003). IPI2 Win A Windows software for an automatic interpretation of resistivity sounding data, $\mathrm{PhD}$ Dissertation Moscow State University, Russia.

http://geophys.geol.msu.ru/ipi2win.htm

Bouwer, H. (1978). Groundwater Hydrology, McGraw - Hill, New York, 210.

Carruthers, R.M. and Smith, I.F. (1992). The use of ground electrical survey methods for siting water - supply boreholes in shallow crystalline basement terrains. In: WRIGHT; E: P8 BURGESS; W:G: (eds.).The hydrogeology of crystalline basement aquifers in Africa. Geological Society Special Publication, 66: 203 - 220.

Chilton, P.J. and Foster, S.S.D. (1995). Hydrogeological characterization and water supply potential of basement aquifers in tropical Africa. Hydrogeology Journal, 3: 36 - 49.

Davis, S.N. and De Wiest, R.J.M. (1966). Hydrology, Wiley, New York, 234.

El-Waheidi, M.M., Merlanti, F. and Pavan, M. (1992). Geoelectrical resistivity survey of the central part of Azraq basin (Jordan) for identifying saltwater/freshwater interface. Journal of Applied Geophysics, 29:125- 133.

Jones, H.A. and Hockey, R.D. (1985). The geology of parts of Southwestern Nigeria. Geological Survey of Nigeria Bulletin, 31: 87

Lashkaripour, G.R. and Nakhaei, M. (2005). Geo-electrical investigation for the assessment of groundwater conditions: A case study. Ann. Geophys. 48: 937-944.

Oyedele, E.A.A. and Olayinka, A.I. (2012). Statistical evaluation of groundwater potential of Ado Ekiti, Southwest, Nigeria. Transnational Journal of Science and Technology, 2(6): 110 - 127

Shrestha, J.N. (1977). Geophysical prospect for mineral deposit, centre for exploration geophysics, Osmania University, India, 79 - 81.

Wright, E.P. (1992). The hydrogeology of crystalline basement aquifers in Africa. Geological Society Special Publication, 66: $1-27$.

Zohdy, A.A.R., Eaton, G.P. and Mabey, D.R. (1974). Application of surface geophysics to groundwater investigation techniques. US Geological Survey, 116. 